\title{
Characterization of Some Quantitative Traits of Locally Developed Tomato Hybrids Under Plastic Tunnels
}

\author{
Aftab Nawaz ${ }^{1}$, Safina Naz ${ }^{1}$, Waqas Ahmad ${ }^{2, *}$, Jamil Shafi ${ }^{3}$, C.M. Ayyub ${ }^{2}$, Muhammad Atiq ${ }^{3}$, \\ Muhammad Mohsin Raza ${ }^{3}$, Mubasher $\mathrm{Ali}^{3}$, Suhail $\mathrm{Asad}^{3}$ \\ ${ }^{1}$ Department of Horticulture, Bahuddin Zakriya University, Multan (60000) Pakistan \\ ${ }^{2}$ Institute of Horticultural Sciences, University of Agriculture, Faisalabad (38040) Pakistan \\ ${ }^{3}$ Department of Plant Pathology, University of Agriculture Faisalabad (38040) Pakistan \\ *Corresponding Author: uaf_waqas@yahoo.com
}

Copyright $@ 2014$ Horizon Research Publishing All rights reserved.

\begin{abstract}
Aim of our work was to compare the performance of the tomato varieties under tunnel conditions and evaluate the yield and fruit quality for both fresh consumption, processing. The experiment was laid out according to completely randomized design. The research consisted of two year (2010-2012) experiments. Both were conducted under tunnel conditions. Data was taken after 30, 60 and 90 days of planting. During the first year experiment $\mathrm{V} 1$ gives the maximum plant height after $30(33.525 \mathrm{~cm}), 60$ $(70.20 \mathrm{~cm})$ and $90(96.537 \mathrm{~cm})$ days of planting while during second year V2 gives the maximum plant height after 30 $(50.850 \mathrm{~cm}), 60(89.102 \mathrm{~cm})$, and $90(113.01 \mathrm{~cm})$ day of planting. V4 gives the maximum number of leaves after 30 (66.337), 60 (96.755) and 90 (126.33) after planting during first year while V4 gives the maximum number of leaves after 30 (86.420), 60 (106.95) and 90 (135.09). During first V3 takes maximum time in first flower (39.50 days) and first fruit (78.98 days) initiation wile during second year V5 was taken maximum time (23.08 days, 44.08) in flower and fruit initiation. During first year V4 (11.57) while during second year V4 (12.75) gives maximum flowers per branch. V1 gives maximum fruits per bunch and fruit diameter, while mortality was recorded maximum in V2 during both years. During first year maximum fresh fruit weight, dry fruit weight, total fresh plant weight, total dry plant weight was recodes in V1 while during second year V2 gives maximum fresh fruit weight and total fresh plant weight. Yield per plant was maximum in V1 during first year while during second year V2gives maximum yield per plant.
\end{abstract}

Keywords Tomato Hybrids, Plastic Tunnels, Quantitative Traits

\section{Introduction}

The Tomato (Lycopersicon esculentum L.) belongs to family solanaceae, was originated in the western coastal plain of South America, extending from Ecuador to Chile [1]. It is native to the Andes region of South America. Tomatoes were introduced to Europe in the 1500 s, although until the 1700s they were believed to be poisonous if eaten, because the foliage and some other green tissues of tomato plants contain tomatine, a toxic chemical. Tomatine is also present in unripe tomato fruit, but the levels are low enough to be non-toxic. Tomatoes are divided into two types. Determinate tomatoes, also called bush or dwarf tomatoes, grow to a certain height, then flower and set all their fruit within a short time. Each shoot on the determinate plant ends in a cluster, and consequently a fruit cluster. The harvest period for determinate tomatoes is generally short, making them good choices for canning [2].

World production is 100 million tons from an area of 3.7 million hectares which is reported for 144 countries of the world [3]. Tomato is an important vegetable crop of Pakistan which is cultivated over an area of about 30.0 thousand hectares with a total production of about 280.0 thousand tones [4].

Tomato varieties can be categorized by their use. For instance, plum tomatoes are used for canning and have thick flesh and a reduced amount of pulp. Beefsteak tomatoes are very large and also have reduced pulp, which makes them excellent for sandwiches and sauces. Classic or salad tomatoes are juicy, since they have a lot of pulp, but this tends to fall out when they are sliced. Schuch and Bird [5] reported that the most relevant qualities of tomatoes vary depending on their intended use: taste, appearance, color and handling characteristic are important for fresh tomatoes, while viscosity and solids are the most important attributes for processing tomatoes. Tomato yield and biomass growth are closely linked to environmental, pedologic and climatic conditions. In the open field, sensitivity to low temperatures limits their geographic distribution and time of year for planting. In Slovenia, the production area for tomato has decreased in the last fifteen years, from 566 ha to 146 ha [6]. Cultivation areas for determinate tomato here are often located in the climatic favourably mediterranean region, 
while the use of plastic tunnels to increase vegetative growth and subsequent yield is needed for successful production of determinate tomato in the middle part of Slovenia.

Tomato (Lycopersicon esculentum L.) is one of the, most important vegetable crops of Pakistan: It is grown on an area of 29.4 thousand hectares and a yield of 294 thousand tons is obtained in Pakistan annually [7].

This annual plant is classified as a warm-season crop with required growing temperature of $25^{\circ} \mathrm{C}$ to $29^{\circ} \mathrm{C}$ [8]. Temperatures even a few degrees above freezing may cause serious damage to both plant and fruit. The optimum temperature for growth, yield and fruit quality of tomatoes is an average daily mean of $20^{\circ} \mathrm{C}$ to $24^{\circ} \mathrm{C}$. At temperatures below $12^{\circ} \mathrm{C}$ or above $35^{\circ} \mathrm{C}$, flowers are often shed. With a consequent poor fruit set; the quality of the fruits produced under such conditions may also be detrimentally affected [9]. The temperature for root development of tomato is from $15^{\prime} \mathrm{C}$ to $30^{\circ} \mathrm{C}$. Tomatoes should ideally be grown in deep, fertile, humus-rich, free-draining, but moisture retentive soils, which are free of nematodes. Sandy loam to clay loam soils are considered to be the most suitable [10].

Tomato is an important vegetable from nutritional stand point. Per $100 \mathrm{~g}$ it contains $0.9 \mathrm{~g}$ of Protein, $3.6 \mathrm{~g}$ of Carbohydrates, $48 \mathrm{mg}$ of Calcium, $20 \mathrm{mg}$ of Phosphorus, 27 $\mathrm{mg}$ of Ascorbic acid, $0.4 \mathrm{mg}$ of Iron, $0.2 \mathrm{~g}$ of Fats, $0.8 \mathrm{~g}$ Fiber and $20 \mathrm{Kcal}$ of energy [11] and it also contains Lycopene and Beta-carotene pigments. Lycopene is a pigment that gives tomatoes their characteristic red color. It is one of hundreds of carotenoids that color fruits and vegetables red, orange or yellow [12]. Tomatoes are good source of Vitamin $\mathrm{C}$ which keeps the blood vessels in good condition and prevents scurvy [13]. Tomatoes are very helpful in healing wounds because of the antibiotic properties found in ripe red fruit. Tomato is used in preserved products like ketch-up, sauce, chutney, soup, paste, puree etc. [14].

Nutritional status of tomato is remarkable as recent studies have revealed that people who eat large amounts of tomatoes or tomato products may be at lower risk of cancer, especially cancer of the prostate gland, lungs and stomach. One pound of fresh tomato has been reported to contain protein $4.0 \mathrm{~g}$, fats 1.22 , carbohydrates $16 \mathrm{mg}$, calcium $40 \mathrm{mg}$, phosphorous 18 $\mathrm{mg}$, iron $2.4 \mathrm{mg}$, thiamine $0.24 \mathrm{mg}$, riboflavin $0.16 \mathrm{mg}$, niacin $2.5 \mathrm{mg}$, ascorbic acid $93 \mathrm{mg}$ and food energy 91 calories [5].

Tomato is with round stems, which are soft and hairy when young, but become angular, hard and almost woody when old. The leaves are alternate, 5-15 inches long, oddpinnate, with seven to nine short stemmed leaflets. The flowers are borne in clusters, located on the stems between the nodes. The fruit is a two to many-celled berry with a fleshy placenta and many small kidney shaped seed, covered with short hairs. Fruit skin has deposition of cutin, varying from cultivar to cultivar [15].

Field limitations such as temperature fluctuations, humidity and frosting are main obstacles in quality production of tomato fruit. In green house all the environmental factors in including temperature, humidity and light are controlled artificially. So, continuous growth and quality produced can be achieved by cultivating under poly tunnels. Ideal environment to some extent can be created to boost up vegetative and reproductive growth and development of tomato plant. Another reason for tomato cultivation in poly tunnels is to exploit vertical growth to get maximum production per unit area.

So, keeping in view the economic value of the crop the aim of our work was to compare the performance of the tomato varieties under tunnel conditions and evaluate the yield and fruit quality for both fresh consumption, processing and for the further recommendation of the farming community.

\section{Materials and Methods}

A research project captioned as "the performance of different tomato hybrids under tunnel conditions" was conducted at the at the experimental area of vegetables, Department of Horticulture, University College of Agriculture, Bahauddin Zakariya University, Multan. The experiment was laid out according to completely randomized design. The research consisted of two experiments. Both were conducted under tunnel conditions in which different vegetative and horticultural parameters were studied. The experiments were carried out during the year 2010-2012. In first year experiment there were four varieties and in second experiment there were six varieties (table1).

Table 1. Names of varieties used during $1^{\text {st }}$ and $2^{\text {nd }}$ year

\begin{tabular}{|c|c|}
\hline $1^{\text {st }}$ year experiment varieties & $2^{\text {nd }}$ year experiment varieties \\
\hline $\mathrm{V} 1=$ Sahel & $\mathrm{V} 1=$ Sahel \\
$\mathrm{V} 2=545$ & $\mathrm{~V} 2=545$ \\
$\mathrm{~V} 3=595$ & $\mathrm{~V} 3=595$ \\
$\mathrm{~V} 4=584$ & $\mathrm{~V} 4=584$ \\
& $\mathrm{~V} 5=559$ \\
$\mathrm{~V} 6=589$ \\
\hline
\end{tabular}

The trial was conducted in a walk in tunnel. Its direction was East-West lengthwise covered with transparent polythene sheet with $0.08 \mathrm{~mm}$ gauge. The nursery seedlings were taken from Department of Vegetable, Ayub Agriculture Research Institute, Faisalabad. Transplanting was done on single side of the raised beds in the tunnel with uniform spacing of $38 \mathrm{~cm}$ as plant to plant distance and $75 \mathrm{~cm}$ as bed to bed distance for all treatments, replicated four times. The seedlings were treated with Ridomil Gold before transplanting. While planting small holes were made in the soil for each transplant. The holes were then filled with soil after keeping the transplants in each hole. The plastic sheet over the tunnel structure was expanded during the first week of January.

In order to ensure heavy fruiting of tomato plants, the following principles in relation to training were adopted. 1) Plants were trained to a single stem with trellis stacking system for better micro-environment. 2) The terminal portion of the stem was trained in a nearly vertical position 
particularly early in the season when light was likely to limit the growth. 3) The growing points were kept in the best light conditions to stimulate growth and flowering. 4) When the plants got established after transplanting, a top cotton string/dori immediately above each plant was tied to the top string of the tunnel. It was ensured that when twisted the string should not immediately touch the truss otherwise the truss could break resulting in the slipping of plant. 5) after 3-4 day period plant off-springs were cut off to keep the plant vertical.

\subsection{Plant Protection Measures}

The plants raised under plastic tunnel are supposed to be protected against insects and diseases. This is feasibly only when the tunnel remains permanently closed that is generally not possible because the tunnel has to be open for air circulation. Therefore different pesticides like Emamectin, Amedacloprid, confidor and fungicides like Score and Ridomil Gold were sprayed during the attack of insect pests and fungus. All other operations were carried out conventionally to obtain best growth of the plants.

\subsection{Collection of Data}

Data was collected on different growth and yield characteristics of tomato. The following parameters were recorded.

\subsubsection{Mortality Percentage}

The total dead plants were counted from each variety and the percentages were calculated using formula:

$$
\frac{\text { No of Dead Plants } \times 100}{\text { Total No of Plants }}
$$

\subsubsection{Plant Height}

The plant height was recorded (30,60 and 90 DAT) with measuring tape by placing it at soil surface by the base of the plant and height was taken up to the tallest growing point.

\subsubsection{No of Leaves per Plant}

The no of leaves per plant were counted $(30,60$ and 90 DAT) and average values were calculated

\subsubsection{First Flower Initiation Time}

The field was visited at alternate days to check the flower initiation time of each variety from the day of transplanting.

\subsubsection{No of Flowers per Bunch}

The no of flowers per bunch were counted and the average values were calculated

\subsubsection{Fruit Setting Percentage per Bunch}

Total no of fully opened flowers and flowers with fruit set were counted and the percentage was calculated using formula:

$$
\frac{\text { No of Fruits } \times 100}{\text { No of Flowers }}
$$

\subsubsection{Fruit Diameter}

The diameters of fruits were taken with the help of vernier calipers and the average values were calculated.

\subsubsection{No of Fruits per Bunch}

The no of fruits per bunch were counted and the average values were calculated.

\subsubsection{Individual Fresh Fruit Weight}

All mature fruits from each plant were taken and weighed with the help of electronic digital balance, average fruit was then calculated

\subsubsection{Time of First Fruit Ripening}

The data of first fruit ripening of each variety was taken and the average values were calculated.

\subsubsection{Fruit Diameter}

The diameters of fruits were taken with the help of vernier calipers and the average values were calculated

\subsubsection{Total Fresh Weight of Plant}

The fresh weight of whole plant was taken with electronic digital balance and the averages were obtained.

\subsubsection{Total Dry Weight of Plant}

The plants were dried in an oven and then weighed and the average values were obtained.

\subsubsection{Leaf Area}

The leaf areas of leaves were taken after 60 days via leaf area meter and the average values were calculated.

\subsubsection{Yield per Plant (Kg)}

The yield data for the individual plant was measured with the help of balance.

\subsubsection{Estimated Yield per Acres (Tones)}

On the basis of actual yield per plant the estimated yield per acre was calculated

\subsection{Statistical Analysis}

The data collected were subjected to statistical analysis as analysis of variance (ANOVA) and Least Significant Difference (LSD) at 5\% level of significance as given by Steel [16] using MSTAT-C.

\section{Results}

\subsection{Plant height}

3.1.1. Plant Height after 30 Days 
During the first year experiment V1 gives the maximum plant height $33.525 \mathrm{~cm}$ followed by V4 and V2 with 28.413 $\mathrm{cm}, 26.263 \mathrm{~cm}$ respectively and $\mathrm{V} 3$ has least plant height $21.063 \mathrm{~cm}$ after 30 days (Table 2). During the second year experiment $\mathrm{V} 2$ gives the maximum plant height $50.850 \mathrm{~cm}$ followed by V1 and V4 with $49.138 \mathrm{~cm}$ and $34.495 \mathrm{~cm}$ respectively. While V5 with $27.120 \mathrm{~cm}$ with least plant height after 30 days (Table 3 ).

\subsubsection{Plant Height after 60 Days}

During the first year experiment V1 gives the maximum plant height $70.20 \mathrm{~cm}$ followed by V4 and V2 with 58.147 $\mathrm{cm}$ and $53.125 \mathrm{~cm}$ respectively. While V3 has least plant height $38.965 \mathrm{~cm}$ after 60 day (Table 2). During the second year experiment V2 gives the maximum plant height 89.102 $\mathrm{cm}$ followed by V1 and V4 with $81.713 \mathrm{~cm}, 67.690$ respectively. While V5 with least plant height has $50.030 \mathrm{~cm}$ after 60 day (Table 3 ).

\subsubsection{Plant Height after 90 Days}

During the first year experiment $\mathrm{V} 1$ gives the maximum plant height $96.537 \mathrm{~cm}$ followed by V4 and V2 with 93.850 $\mathrm{cm}$ and $77.088 \mathrm{~cm}$ respectively. V 62.6023 with has least plant height after 90 days (Table 2). During the second year experiment V2 gives the maximum plant height $113.01 \mathrm{~cm}$ followed by V1 and V4 with $112.47 \mathrm{~cm}$ and $105.02 \mathrm{~cm}$ respectively. While V6 with $81.05 \mathrm{~cm}$ has least plant height after 90 days (Table 3 ).

\subsection{No of Leaves per Plant}

\subsubsection{No of Leaves per Plant after 30 Days}

During the first year experiment V4 gives the maximum number of leaves 66.337 after 30 days followed by V1 and V3 with 54.898 and 42.932 respectively. V2 with 38.823 least number of leaves per plant after 30 days (Table 2). During the second year experiment V4 gives the maximum number of leaves 86.420 after 30 days followed by V2 and V1 with 68.767 and 67.523 respectively. While V5 with the 56.998 has least number of leaves per plant after 30 days (Table 3).

\subsubsection{No of Leaves per Plant after 60 Days}

During the first year experiment V4 gives the maximum number of leaves 96.755 after 60 days followed by V1 and V3 with 92.442 and 83.782 respectively, While V2 with 78.238 has least number of leaves per plant after 60 days (Table 2). During the second year experiment V4 gives the maximum number of leaves 106.95 after 60 days followed by V2 and V1 with 100.05 and 93.84 respectively. V5 (78.73) has least number of leaves per plant after 60 days (Table 3 ).

\subsubsection{No of Leaves Per Plant After 90 Days}

During the first year experiment V1 gives the maximum number of leaves 126.33 after 90 days followed by V4 and V2 with 120.88 and 111.75 respectively. V3 with 108.40 has minimum number leaves per plant after 90 days (Table 3 ). During the second year experiment V4 gives the maximum number of leaves 135.09 after 90 days followed by V2 and V1, with 128.72 , and 119.98 respectively and V5 with least number of leaves after 90 days 100.21 (Table 3 ).

\subsection{No of Leaves per Plant}

During the first year experiment V3 gives the maximum 39.502 days followed by V2 and V4 with 30.150 and 27.570 days respectively and V 24.635 with days least flower initiation time (Table 2). During the second year experiment V5 gives the maximum 23.075 days followed by V3 and V6 with22.600 and 21.953 days respectively and V2 with 10.428 days least flower initiation time (Table 3 ).

\subsection{Fruit Initiation Time}

During the first year experiment V3 gives the maximum 78.975 days followed by V2 and V4 with 61.225 and 52.950 days respectively and V1 with 47.800 days least fruit initiation time (Table 2). During the second year experiment V5 gives the maximum 44.075 days followed by V3 and V6 with 43.225 and 38.550 days respectively and V2 with 21.550 days least fruit initiation time (Table 3 ).

\subsection{No of Flowers per Bunch}

During the first year experiment V4 gives the maximum 11.565 followed by V1 and V2 with 6.332 and 5.775 respectively and V3 with 5.603 least number of flower per bunch (Table 2). During the second year experiment V4 gives the maximum 12.750 followed by V2 and V1 with 8.375 and 6.875 respectively and $\mathrm{V} 3$ with 5.188 least number of flower per bunch (Table 3).

\subsection{Fruit Setting Percentage per Bunch}

During the first year experiment V1 gives the maximum 55.00 followed by V3 and V2 with 46.250 and 43.250 respectively and V4 with 41.500 least fruit setting percentage per bunch (Table 2). During the second year experiment V1 gives the maximum 52.250 followed by V3 and V2, with 46.250 and 43.500 respectively and V4 with 36.250 least fruit setting percentage per bunch (Table 3).

\subsection{Mortality Percentage}

During the first year experiment V2 gives the maximum 42.500 followed by $\mathrm{V} 1$ and $\mathrm{V} 3$ with 10 and 4.25 respectively and V4 with 0 least mortality percentage (Table 2). During the second year experiment $\mathrm{V} 2$ gives the maximum 18.750 followed by V1 and V3 with 12.50 and 6.25 respectively and V5 with 0 least mortality percentage (Table 3 ).

\subsection{Fruit Diameter}


During the first year experiment $\mathrm{V} 1$ gives the maximum $4.15 \mathrm{~cm}$ followed by V3 and V2 with 3.8 and $3.35 \mathrm{~cm}$ respectively and V4 with $2.80 \mathrm{~cm}$ least fruit diameter (Table 2 ). During the second year experiment V1 gives the maximum $4.37 \mathrm{~cm}$ followed by V2 and V5 with 4.2 and 3.97 $\mathrm{cm}$ respectively and $\mathrm{V} 4$ with $3.52 \mathrm{~cm}$ least fruit diameter (Table 3).

\subsection{No of Flowers per Plant}

During the first year experiment V1 gives the maximum 11.00 followed by V2 and V4 with 10.93 and 10.56 respectively and V3 with 8.68 least number of flowers per plant (Table 2). During the second year experiment V4 gives the maximum 11.50 followed by V1 and V2 bot with 11.25 and $\mathrm{V} 3$ with 8.87 least number of flowers per plant (Table 3 ).

\subsection{Individual Fresh Fruit Weight}

During the first year experiment V1 gives the maximum $52.250 \mathrm{~g}$ followed by V3 and V2 with 42.90 and $36.23 \mathrm{~g}$ respectively and V4 with $35.39 \mathrm{~g}$ least individual fresh fruit weight (Table 2). During the second year experiment V2 gives the maximum $64.525 \mathrm{~g}$ followed by V1 and V5 with 60.99 and $46.87 \mathrm{~g}$ respectively and V6 with $41.77 \mathrm{~g}$ least individual fresh fruit weight (Table 3).

\subsection{Individual Dry Fruit Weight}

During the first year experiment V1 gives the maximum $1.54 \mathrm{~g}$ followed by V3 and V2 with $1.30 \mathrm{~g}$ and $1.10 \mathrm{~g}$ respectively and V4 with $1.05 \mathrm{~g}$ least individual dry fruit weight (Table 22). During the second year experiment V1 gives the maximum $3.53 \mathrm{~g}$ followed by V2 and V3 with 3.46 $\mathrm{g}$ and $2.54 \mathrm{~g}$ respectively and V6 with $2.20 \mathrm{~g}$ least individual dry fruit weight (Table 3 ).

\subsection{Total Fresh Weight of Plant}

During the first year experiment V1 gives the maximum $323.05 \mathrm{~g}$ followed by V3 and V4 with $289.25 \mathrm{~g}$ and $252.95 \mathrm{~g}$ respectively and V2 with $220.17 \mathrm{~g}$ least fresh weight of plant (Table 2). During the second year experiment V2 gives the maximum $386.39 \mathrm{~g}$ followed by V4 and V1 with $366.80 \mathrm{~g}$ and $348.95 \mathrm{~g}$ respectively and V5 with $288.31 \mathrm{~g}$ least fresh weight of plant (Table 3).

\subsection{Total Dry Weight of Plant}

During the first year experiment $\mathrm{V} 1$ gives the maximum $37.90 \mathrm{~g}$ followed by V3 and V2 with $27.47 \mathrm{~g}$ and $24.44 \mathrm{~g}$ respectively and V4 with 22.74 g least dry weight of plant (Table 2). During the second year experiment V1 gives the maximum $30.370 \mathrm{~g}$ followed by V4 and V2 with $29.44 \mathrm{~g}$ and $29.29 \mathrm{~g}$ respectively and V3 with $21.13 \mathrm{~g}$ least dry weight of plant (Table 3).

\subsection{Leaf Area}

During the first year experiment V4 gives the maximum 120.16 followed by V1 and V3 with 115.56 and 106.37 respectively and V2 with 98.21 least leaf area (Table 2). During the second year experiment V2 gives the maximum 160.17 followed by V4 and V1 with 154.67 and 108.39 respectively and V5 with 96.87 least leaf area (Table 3).

\subsection{Yield per Plant (Kg)}

During the first year experiment $\mathrm{V} 1$ gives the maximum $8.71 \mathrm{Kg}$ followed by V4 and V2 with $8.6 \mathrm{Kg}$ and $6.4 \mathrm{Kg}$ respectively and V3 with $6.3 \mathrm{Kg}$ least yield per plant (Table 2). During the second year experiment V2 gives the maximum $10.46 \mathrm{Kg}$ followed by V4 and V1 with $9.63 \mathrm{Kg}$ and $9.17 \mathrm{Kg}$ respectively and $\mathrm{V} 3$ with $6.9 \mathrm{Kg}$ least yield per plant (Table 3). 
Table 2. Response of different tomato hybrids cultivars for different quantitative traits during first year

\begin{tabular}{|c|c|c|c|c|c|c|c|c|c|c|c|c|c|c|c|c|c|c|c|}
\hline \multirow{2}{*}{ 产. } & \multicolumn{3}{|c|}{ Plant Height } & \multicolumn{3}{|c|}{ No. of Leaves/plant } & \multirow{2}{*}{$\begin{array}{c}\text { Flower } \\
\text { Initiatio } \\
\text { n Time } \\
\text { (days) }\end{array}$} & \multirow{2}{*}{$\begin{array}{c}\text { Fruit } \\
\text { Initiatio } \\
\mathrm{n} \text { Time } \\
\text { (days) }\end{array}$} & \multirow{2}{*}{$\begin{array}{l}\text { No. of } \\
\text { Flowers } \\
\text { / Bunch }\end{array}$} & \multirow{2}{*}{$\begin{array}{c}\text { Fruit } \\
\text { Setting/ } \\
\text { Bunch } \\
(\%)\end{array}$} & \multirow{2}{*}{$\begin{array}{c}\text { Mortalit } \\
\text { y (\%) }\end{array}$} & \multirow{2}{*}{$\begin{array}{c}\text { Fruit } \\
\text { Diamet } \\
\text { er } \\
(\mathrm{cm} 3)\end{array}$} & \multirow{2}{*}{$\begin{array}{c}\text { No. } \\
\text { Flowers } \\
\text { /plant }\end{array}$} & \multirow{2}{*}{$\begin{array}{c}\text { Fresh } \\
\text { Fruit } \\
\text { Weight } \\
(\mathrm{g})\end{array}$} & \multirow{2}{*}{$\begin{array}{c}\text { Dry } \\
\text { Fruit } \\
\text { Weight } \\
\text { (g) }\end{array}$} & \multirow{2}{*}{$\begin{array}{c}\text { Total } \\
\text { Fresh } \\
\text { Wt./Pla } \\
\text { nt (g) }\end{array}$} & \multirow{2}{*}{$\begin{array}{c}\text { Total } \\
\text { Dry } \\
\text { Wt./Pla } \\
\text { nt (g) }\end{array}$} & \multirow{2}{*}{$\begin{array}{l}\text { Leaf } \\
\text { Area } \\
(\mathrm{cm} 2)\end{array}$} & \multirow{2}{*}{$\begin{array}{l}\text { Yield/P } \\
\text { lant (g }\end{array}$} \\
\hline & 30 days & 60 days & 90 days & 30 days & 60 days & 90 days & & & & & & & & & & & & & \\
\hline $\mathrm{V}$ & 2 & & & & & & 24.635 & 47.800 & & 55.000 & & 4.1500 & 11.0 & 52.250 & 1.5475 & 323.05 & 37.907 & & 125 \\
\hline V1 & A & t & $\mathrm{A}$ & $\mathrm{B}$ & & 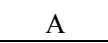 & $\mathrm{D}$ & $\mathrm{C}$ & & A & 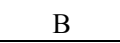 & A & & A & A & A & $\mathrm{A}$ & & A \\
\hline V2 & $\begin{array}{c}26.263 \\
\mathrm{AB}\end{array}$ & $\begin{array}{c}53.125 \\
\text { B }\end{array}$ & $\begin{array}{c}77.088 \\
\text { B }\end{array}$ & $\begin{array}{c}38.823 \\
\mathrm{C}\end{array}$ & $\begin{array}{c}78.238 \\
\mathrm{C}\end{array}$ & $\begin{array}{c}111.75 \\
\text { B }\end{array}$ & $\begin{array}{c}30.150 \\
\text { B }\end{array}$ & $\begin{array}{c}61.225 \\
\text { B }\end{array}$ & $5.775 \mathrm{~B}$ & $\begin{array}{c}43.250 \\
\text { A }\end{array}$ & $\begin{array}{c}42.500 \\
\mathrm{~A}\end{array}$ & $\begin{array}{c}3.3500 \\
\text { BC }\end{array}$ & $\begin{array}{c}10.938 \\
\mathrm{~A}\end{array}$ & $\begin{array}{c}36.230 \\
\mathrm{C}\end{array}$ & $\begin{array}{c}1.1000 \\
\mathrm{C}\end{array}$ & $\begin{array}{c}220.17 \\
C\end{array}$ & $\begin{array}{c}24.445 \\
\text { B }\end{array}$ & $21 \mathrm{~A}$ & $\begin{array}{c}6.4200 \\
\text { B }\end{array}$ \\
\hline V3 & $\begin{array}{c}21.063 \\
\text { B }\end{array}$ & $\begin{array}{c}38.965 \\
\mathrm{C}\end{array}$ & $\begin{array}{c}62.602 \\
\mathrm{C}\end{array}$ & $\begin{array}{c}42.932 \\
C\end{array}$ & $\begin{array}{c}83.782 \\
\text { BC }\end{array}$ & $108.0 \mathrm{~B}$ & $\begin{array}{c}39.502 \\
\mathrm{~A}\end{array}$ & $\begin{array}{c}78.975 \\
\text { A }\end{array}$ & 5.603 & $\begin{array}{c}46.250 \\
\text { A }\end{array}$ & $\begin{array}{c}4.2500 \\
\text { B }\end{array}$ & $\begin{array}{c}3.8000 \\
\mathrm{AB}\end{array}$ & 8.688 & $\begin{array}{c}42.990 \\
\text { B }\end{array}$ & $1.302 \mathrm{~B}$ & $\begin{array}{c}289.25 \\
\mathrm{AB}\end{array}$ & $\begin{array}{c}27.475 \\
\text { B }\end{array}$ & $\begin{array}{c}106.37 \\
\text { A }\end{array}$ & $\begin{array}{c}6.3875 \\
\text { B }\end{array}$ \\
\hline V4 & $\begin{array}{c}28.413 \\
\mathrm{AB}\end{array}$ & $\begin{array}{c}58.147 \\
\text { B }\end{array}$ & $\begin{array}{c}93.850 \\
\mathrm{~A}\end{array}$ & $\begin{array}{c}66.337 \\
\text { A }\end{array}$ & $\begin{array}{c}96.755 \\
\text { A }\end{array}$ & $\begin{array}{c}120.88 \\
\mathrm{AB}\end{array}$ & $\begin{array}{c}27.570 \\
\text { C }\end{array}$ & $\begin{array}{c}52.950 \\
\mathrm{C}\end{array}$ & $\begin{array}{c}11.565 \\
\mathrm{~A}\end{array}$ & $\begin{array}{c}41.500 \\
\mathrm{~A}\end{array}$ & $\begin{array}{c}0.0000 \\
\text { B }\end{array}$ & $\begin{array}{c}2.8000 \\
\mathrm{C}\end{array}$ & $\begin{array}{c}10.563 \\
\text { A }\end{array}$ & $\begin{array}{c}35.393 \\
\text { C }\end{array}$ & $\begin{array}{c}1.0550 \\
\mathrm{C}\end{array}$ & $\begin{array}{c}252.95 \\
\mathrm{BC}\end{array}$ & $\begin{array}{c}22.747 \\
\text { B }\end{array}$ & $\begin{array}{c}120.16 \\
\mathrm{~A}\end{array}$ & $\begin{array}{c}8.6350 \\
\mathrm{~A}\end{array}$ \\
\hline
\end{tabular}

*Mean values sharing similar letters do not differ significantly as determined by the LSD test at $5 \%$ level of probability

Table 3. Response of different tomato hybrids cultivars for different quantitative traits during second year

\begin{tabular}{|c|c|c|c|c|c|c|c|c|c|c|c|c|c|c|c|c|c|c|c|}
\hline \multirow{2}{*}{. } & \multicolumn{3}{|c|}{ Plant Height } & \multicolumn{3}{|c|}{ No. of Leaves/plant } & \multirow{2}{*}{$\begin{array}{c}\text { Flower } \\
\text { Initiatio } \\
\mathrm{n} \text { Time } \\
\text { (days) }\end{array}$} & \multirow{2}{*}{$\begin{array}{c}\text { Fruit } \\
\text { Initiatio } \\
\text { n Time } \\
\text { (days) }\end{array}$} & \multirow{2}{*}{$\begin{array}{l}\text { No. of } \\
\text { Flowers } \\
\text { / Bunch }\end{array}$} & \multirow{2}{*}{$\begin{array}{c}\text { Fruit } \\
\text { Setting/Bunc } \\
\text { h (\%) }\end{array}$} & \multirow{2}{*}{$\begin{array}{c}\text { Mortalit } \\
\text { y (\%) }\end{array}$} & \multirow{2}{*}{$\begin{array}{c}\text { Fruit } \\
\text { Diamete } \\
r\end{array}$} & \multirow{2}{*}{$\begin{array}{c}\text { No. } \\
\text { Flowers/pla } \\
\text { nt }\end{array}$} & \multirow{2}{*}{\begin{tabular}{|c|} 
Fresh \\
Fruit \\
Weigh \\
$\mathrm{t}(\mathrm{g})$
\end{tabular}} & \multirow{2}{*}{$\begin{array}{c}\text { Dry } \\
\text { Fruit } \\
\text { Weigh } \\
\mathrm{t}(\mathrm{g})\end{array}$} & \multirow{2}{*}{$\begin{array}{c}\text { Total } \\
\text { Fresh } \\
\text { Wt./Plan } \\
\mathrm{t}(\mathrm{g})\end{array}$} & \multirow{2}{*}{$\begin{array}{c}\text { Total } \\
\text { Dry } \\
\text { Wt./Plan } \\
\mathrm{t}(\mathrm{g})\end{array}$} & \multirow{2}{*}{$\begin{array}{l}\text { Leaf } \\
\text { Area }\end{array}$} & \multirow{2}{*}{$\begin{array}{l}\text { Yield/Plan } \\
\mathrm{t}(\mathrm{g}\end{array}$} \\
\hline & $\begin{array}{c}30 \\
\text { days }\end{array}$ & $\begin{array}{c}60 \\
\text { days }\end{array}$ & $\begin{array}{c}90 \\
\text { days }\end{array}$ & $\begin{array}{c}30 \\
\text { days }\end{array}$ & $\begin{array}{c}60 \\
\text { days }\end{array}$ & $\begin{array}{c}90 \\
\text { days }\end{array}$ & & & & & & & & & & & & & \\
\hline $\begin{array}{l}\mathrm{V} \\
1 \\
\end{array}$ & $\begin{array}{c}49.13 \\
8 \mathrm{~A} \\
\end{array}$ & $\begin{array}{c}81.71 \\
3 \mathrm{~A} \\
\end{array}$ & $\begin{array}{c}112.4 \\
7 \mathrm{~A} \\
\end{array}$ & $\begin{array}{l}67.52 \\
3 \mathrm{BC}\end{array}$ & $\begin{array}{c}93.84 \\
\mathrm{BC}\end{array}$ & $\begin{array}{l}119.9 \\
8 \mathrm{BC}\end{array}$ & $\begin{array}{c}11.110 \\
\mathrm{BC}\end{array}$ & $\begin{array}{c}25.325 \\
\mathrm{BC}\end{array}$ & $6.875 \mathrm{C}$ & $52.250 \mathrm{~A}$ & 12.500 & $\begin{array}{c}4.3750 \\
\text { A }\end{array}$ & $11.250 \mathrm{AB}$ & $\begin{array}{c}60.993 \\
\text { A }\end{array}$ & $\begin{array}{c}3.5375 \\
\mathrm{~A}\end{array}$ & $\begin{array}{c}348.95 \\
\mathrm{ABC}\end{array}$ & 30.370 & $\begin{array}{c}108.3 \\
9 \mathrm{~B} \\
\end{array}$ & $9.178 \mathrm{BC}$ \\
\hline $\begin{array}{l}\mathrm{V} \\
2\end{array}$ & $\begin{array}{c}50.85 \\
0 \mathrm{~A}\end{array}$ & $\begin{array}{c}89.10 \\
2 \mathrm{~A}\end{array}$ & $\begin{array}{c}113.0 \\
1 \mathrm{~A}\end{array}$ & $\begin{array}{c}68.76 \\
7 \mathrm{~B}\end{array}$ & $\begin{array}{l}100.0 \\
5 \mathrm{AB}\end{array}$ & $\begin{array}{l}128.7 \\
2 \mathrm{AB}\end{array}$ & $\begin{array}{c}10.428 \\
\mathrm{C}\end{array}$ & $\begin{array}{c}21.550 \\
\mathrm{C}\end{array}$ & $8.375 \mathrm{~B}$ & $43.500 \mathrm{BC}$ & 18.750 & $\begin{array}{c}4.200 \\
\mathrm{AB}\end{array}$ & $11.250 \mathrm{AB}$ & $\begin{array}{c}64.525 \\
\text { A }\end{array}$ & $\begin{array}{c}3.4625 \\
\text { A }\end{array}$ & $\begin{array}{c}386.39 \\
\text { A }\end{array}$ & 29.293 & $\begin{array}{c}160.1 \\
7 \mathrm{~A}\end{array}$ & $10.465 \mathrm{~A}$ \\
\hline $\begin{array}{l}\mathrm{V} \\
3\end{array}$ & $\begin{array}{l}30.76 \\
0 \mathrm{BC} \\
\end{array}$ & $\begin{array}{c}53.84 \\
0 \mathrm{C} \\
\end{array}$ & $\begin{array}{c}85.02 \\
\text { B }\end{array}$ & $\begin{array}{l}60.62 \\
5 \mathrm{CD} \\
\end{array}$ & $\begin{array}{c}85.51 \\
\text { CD }\end{array}$ & $\begin{array}{c}105.5 \\
7 \mathrm{D} \\
\end{array}$ & $\begin{array}{c}22.600 \\
\mathrm{~A}\end{array}$ & $\begin{array}{c}43.225 \\
\text { A }\end{array}$ & $5.188 \mathrm{D}$ & $46.250 \mathrm{~B}$ & 6.2500 & $\begin{array}{c}3.9250 \\
\text { BC }\end{array}$ & $8.875 \mathrm{D}$ & $\begin{array}{c}46.613 \\
\text { B }\end{array}$ & $\begin{array}{c}2.5425 \\
\text { B }\end{array}$ & $\begin{array}{c}296.95 \\
\text { CD }\end{array}$ & 21.135 & $\begin{array}{c}98.76 \\
\text { B }\end{array}$ & $6.983 \mathrm{D}$ \\
\hline $\begin{array}{l}\mathrm{V} \\
4\end{array}$ & $\begin{array}{c}34.49 \\
5 \mathrm{~B}\end{array}$ & $\begin{array}{c}67.69 \\
0 \mathrm{~B}\end{array}$ & $\begin{array}{c}105.0 \\
2 \mathrm{~A}\end{array}$ & $\begin{array}{c}86.42 \\
0 \mathrm{~A}\end{array}$ & $\begin{array}{c}106.9 \\
5 \mathrm{~A}\end{array}$ & $\begin{array}{c}135.0 \\
9 \mathrm{~A}\end{array}$ & $\begin{array}{c}14.688 \\
\text { B }\end{array}$ & $\begin{array}{c}29.275 \\
\text { B }\end{array}$ & $\begin{array}{c}12.750 \\
\mathrm{~A}\end{array}$ & 3 & 0 & $\begin{array}{c}3.5250 \\
\mathrm{D}\end{array}$ & $11.500 \mathrm{~A}$ & $\begin{array}{c}44.500 \\
\text { BC }\end{array}$ & $\begin{array}{c}2.4100 \\
\text { BC }\end{array}$ & $\begin{array}{c}366.80 \\
\mathrm{AB}\end{array}$ & 29.445 & $\begin{array}{c}154.6 \\
7 \mathrm{~A}\end{array}$ & $9.630 \mathrm{AB}$ \\
\hline $\begin{array}{l}\mathrm{V} \\
5 \\
\end{array}$ & $\begin{array}{c}27.12 \\
0 \mathrm{C} \\
\end{array}$ & $\begin{array}{c}50.03 \\
0 \mathrm{C} \\
\end{array}$ & $\begin{array}{c}83.99 \\
\text { B }\end{array}$ & $\begin{array}{c}56.99 \\
8 \mathrm{D} \\
\end{array}$ & $\begin{array}{c}78.73 \\
\mathrm{D} \\
\end{array}$ & $\begin{array}{c}100.2 \\
1 \mathrm{D} \\
\end{array}$ & $\begin{array}{c}23.075 \\
\mathrm{~A}\end{array}$ & $\begin{array}{c}44.075 \\
\mathrm{~A}\end{array}$ & $5.250 \mathrm{D}$ & $39.250 \mathrm{CD}$ & 0.0000 & $\begin{array}{c}3.9750 \\
\text { B }\end{array}$ & $9.188 \mathrm{CD}$ & $\begin{array}{c}46.875 \\
\text { B }\end{array}$ & $\begin{array}{c}2.4100 \\
\text { BC }\end{array}$ & $\begin{array}{c}288.31 \\
\text { D }\end{array}$ & 21.713 & $\begin{array}{c}96.87 \\
\text { B }\end{array}$ & $8.088 \mathrm{CD}$ \\
\hline $\begin{array}{l}\mathrm{V} \\
6\end{array}$ & $\begin{array}{l}32.21 \\
2 \mathrm{BC}\end{array}$ & $\begin{array}{c}51.72 \\
2 \mathrm{C}\end{array}$ & $\begin{array}{c}81.05 \\
\text { B }\end{array}$ & $\begin{array}{c}57.74 \\
7 \mathrm{D}\end{array}$ & $\begin{array}{l}88.53 \\
\text { BCD }\end{array}$ & $\begin{array}{l}106.6 \\
4 \mathrm{CD}\end{array}$ & $\begin{array}{c}21.953 \\
\mathrm{~A}\end{array}$ & $\begin{array}{c}38.550 \\
\mathrm{~A}\end{array}$ & $5.433 \mathrm{D}$ & $42.500 \mathrm{BC}$ & 6.2500 & $\begin{array}{c}3.6000 \\
\mathrm{CD}\end{array}$ & $10.188 \mathrm{BC}$ & $\begin{array}{c}41.775 \\
C\end{array}$ & $\begin{array}{c}2.2250 \\
\mathrm{C}\end{array}$ & $\begin{array}{c}316.82 \\
\text { BCD }\end{array}$ & 25.615 & $\begin{array}{c}99.09 \\
\text { B }\end{array}$ & $8.225 \mathrm{CD}$ \\
\hline
\end{tabular}

*Mean values sharing similar letters do not differ significantly as determined by the LSD test at $5 \%$ level of probability 


\section{Discussion}

Field limitations such as temperature fluctuations, humidity and frosting are main obstacles in quality production of tomato fruit. In green house all the environmental factors in including temperature, humidity and light are controlled artificially. The results of present study regarding plant height was coincide with the findings of Haque [17] who reported that line TMO 369 produced the tallest plant $(116.60 \mathrm{~cm})$ and line TMO 260 gave the shortest plants of $47.63 \mathrm{~cm}$ height during evaluation of tomato lines. Kallo [18] and Manoj and Ragav [15] also reported differences in plant height among cultivars/hybrids of tomato put under evaluation and screening trials.

Present study showed that increasing tendency in the number of branches per plant with an increase in the plant height. Phookan [19] reported variations among the hybrids in plant height when tomato was grown in summer under plastic house condition.

In present study plant vary with respect to height these results coincide with the findings of Haque [16] who reported that line TMO 369 produced the tallest plant $(116.60 \mathrm{~cm})$ and line TMO 260 gave the shortest plants of $47.63 \mathrm{~cm}$ height during evaluation of tomato lines. Kallo [18] and Manoj and Ragav [15] also reported differences in plant height among cultivars/hybrids of tomato put under evaluation and screening trials. The number of leaves in a plant depends upon the continuity of nodes plus the vigor of the plant. There is always an optimum period for a particular crop to grow under some specific environment. It means that plants germinating under favorable conditions will seek advantage of giving good and healthy plants as compared with plants germinating in a comparatively unfavorable environment. Number of leaves correlate the growth and yield. This is fundamental determinant of total fresh leaves yield per plant. The early or late maturity is attributed as genotypic character and somewhat influenced by the environmental factors of any particular growing area. Jaha and Krishi [20] reported that under direct sowing method cultivar Naveen gave the earliest fruit maturity (80.33 DAS) while under transplanting method cultivar Vaishali recorded the earliest fruit maturity $(84.00$ DAS).The results correspond to the findings of Phookan [19] who reported similar results.

The results were similar to those of studied by Smith [21] who reported a big increase in blossom drop resulting from hot and dry wind and low humidity. Study indicated that all the varieties differ in yield these results resemble with those of Jaha and Krishi [20] who reported that among 4 hybrid cultivars of tomato Abinash recorded the highest number of fruits per plant (69.07).

The results are similar to those found by Dane [22] who stated that small fruited abundantly flowering genotypes were less affected by heat stress than larger fruited cultivars, which supports the results of this experiment. Jaha and Krishi [20] reported $4.03 \mathrm{~kg}$ fresh fruit yield per plant in cultivar Naveen. Ahmad [23] also found the range of individual fruit weight to be from $5.25 \mathrm{~g}$ to $43.38 \mathrm{~g}$ among 25 heat tolerant hybrids which supports the findings of the present study. Differences in dry fruit yield might be due to differences in fresh fruit yield and nature of fruits in term of their succulence and dry matter content. Manoj and Ragav [15] reported maximum dry matter by Pant T-3 used as control among 11 tomato cultivars studied for their performance.

There is a direct relation between the number of leaves and the leaf surface area under sowing dates. It can be visualized that in some cases the number of leaves must be greater but the dimension of leaves might obtain a reverse position. Moreover the favorable growing conditions promote vegetative growth including the leaf size. As the leaf size is directly proportional to the leaf surface area. Hence, it can be visualized when the leaf size increases the leaf surface area also increases.

The results this study comply with the findings of Jaha and Krishi [20] who recorded the highest harvesting yield of 16 $\mathrm{kg}$ in cultivar Naveen under the transplanting method. While Rida [24] reported that marketable yield ranged from $76.18 \mathrm{t}$ ha-1 (Rio grande) to $37.07 \mathrm{t}$ ha-1 (Money maker) in thirteen open pollinated cultivars and three hybrids of tomato screened for yield and growth characters. Baki [25] conducted an experiment on heat tolerant tomato under high temperature 372 Alam [26] conditions $\left(39^{\circ} \mathrm{C}\right.$ day $/ 28^{\circ} \mathrm{C}$ night) and reported that yield of tomato varied depending on the level of heat tolerance of the hybrids. Findings of Ahmad [23] also support the results of this trial.

\section{REFERENCES}

[1] J. R. Harlan. Crops and Man. $2^{\text {nd }}$ (ed.) American Society of Agronomy, Crop Sciences of America, Madison, 1992.

[2] C. Moraru, L. Logendra, T. C. Lee, H. Janes. Characteristics of 10 processing tomato cultivars grown hydroponically for the NASA Advances Life Support Program. Journal of Food Composition and Analysis, Vol.17, 141-154, 2004.

[3] FAO. 2008. FAO stat database available online from www.fao.org.

[4] Anonymous. Agricultural Statistics of Pakistan, Govt. of Pakistan, Ministry of Food, Agriculture and Livestock Economic Wing, Islamabad, 2008.

[5] W. Schuch, C. Bird. Improving tomato fruit quality using biosience, Acta Horticulturae, Vol.376, 75-80, 1994.

[6] Statistični letopis Slovenije, available online from http://www.sigov.si/zrs/publikacije/leto/letops_s.html.

[7] GOP database available online from www.gao.org.

[8] R. R. Gautam, B.S. Dhankar, F. Kalloo. Evaluation of tomato genotypes for fruit set under low temperature conditions, Journal of Horticultural Sciences, Vol.10, 81-82, 1982.

[9] S. Iwahori, K. Takahashi. Effects of high temperature on 
flower buds and flowers of different stages development, Journal of Japanese Society of Horticultural Sciences, Vol.33, 67-74, 1964.

[10] A. Rashid, J. Ryan. Micronutrients constrains to crop production in soils with Mediterranean-type characteristics, Journal of Plant Nutrition, Vol.27, No.6, 959-975, 2004.

[11] B. V. Goplan, Ramasastri, S.C Alasubrananian. Nutritive value of Indian Foods. National institute of Nutrition, Hyderabad, 1980.

[12] O. P. Gupta, S. Siddiqui, S. La. 1989. Quality assessment of tomato (Lycopersicum esculentum Mill.) varieties, Agricultural Sciences digest, Vol.9, No.3, 123-126, 1989.

[13] K. G. Shanmugavelu. Production technology of Vegetable Crop. Oxford \& IBH Co. Pvt. Ltd., New Dehli, 1989.

[14] S. S. Nielsen. Introduction to the Chemical analysis of food. Fruit and vegetable products, Punjab Horticultural Journal, Vol.16, 113-114, 1994.

[15] R. Manoj, M. Raghav. 1998. Performance of F1 hybrids and high yielding varieties of tomato under mid-west plains of Uttar Pardesh, Progressive Horticulture, Vol.30, No.3, 194-197, 1998.

[16] R. D. G. Steel, J.H. Torrie, D.A. Deekey. Principles and procedures of statistics. A biometrical approach.3rd Ed. McGraw Hill, New York, 1997.

[17] M. M. Haque, A.K.M. Rehman, S.M.M. Hossain. Physiological and yield potential of some promising tomato lines at different planting times, Pakistan Journal of Agricultural Research, Vol.9, No.3, 359-362, 1998.

[18] G. Kallo, S.N.G. Chaurasia, S. Major, M. Singh. Stability analysis in tomato. Vegetable Science, Vol.25, No.1, 81-84, 1998.
[19] D. B. Phookan, P. Talukdar, A. Shadeque, B.K. Chakravarty. Genetic variability and heritability in tomato (Lycopersicon escuiuntum) genotypes during summer season under plastic-house condition. Indian Journal of Agricultural Sciences, Vol.68, No.6, 304-314, 1990.

[20] J. C. Jaha, B. Krishi. Studies on performance of different tomato hybrids in off-season under different planting methods in Terai agro-climatic zones of West Bengal, Indian Journal of Interacademicia, Vol.5, No.2, 186-189, 2001.

[21] O. Smith. Regulation of temperature to anthesis and blossom drop of the tomato, together with a histological study of the pistils, Journal of Agricultural Research, Vol.44, 183-190, 1982.

[22] F. Dane, A. G. Hunter, O. L. Chambliss. Fruit set, pollen fertility and combining ability of selected tomato genotypes under high temperature field conditions. Journal of American Society for Horticultural Sciences, Vol.116, No.5, 906-910, 1991.

[23] S. Ahmad. . Genetics of fruit set and related traits in tomato under hot -humid conditions. Ph. D. Thesis, BSMRAU. 44-180, 2002.

[24] A. S. Rida, A.A. Muhammad, I.E. Ereifij, A. Hussain. Evaluation of thirteen open pollinated cultivars and three hybrids of tomato (Lycopersicon esculentum Mill.) for yield, physiological disorders, seed production and vegetative growth, Pakistan Journal of Agricultural Research. Vol.17, No.3, 290- 296, 2002.

[25] A. A. Baki. Tolerance of tomato cultivars and selected germplasm to heat stress, Journal of American Society for Horticultural. Sciences, 48-55, 1991.

[26] M. S. Alam, N. Sultana, S. Ahmad M.M. Hossain, A. K. M. A. Islam. Performance of heat tolerant tomato hybrid lines under hot, humid conditions, Journal of . Agricultural Research, Vol.3, 367-373, 2010 